\title{
Overheated Underdogs: Civilizational Analysis and Migration on the Danube-Tisza Interfluve
}

\section{Chris Hann}

To cite this article: Chris Hann (2016) Overheated Underdogs: Civilizational Analysis and Migration on the Danube-Tisza Interfluve, History and Anthropology, 27:5, 602-616, DOI: 10.1080/02757206.2016.1219353

To link to this article: http://dx.doi.org/10.1080/02757206.2016.1219353
(c) 2016 The Author(s). Published by Informa UK Limited, trading as Taylor \& Francis Group
曲 Published online: 31 Aug 2016.

Submit your article to this journal $\pi$

Llll Article views: 315

Q View related articles ¿

View Crossmark data $₫$ 


\title{
Overheated Underdogs: Civilizational Analysis and Migration on the Danube-Tisza Interfluve
}

\author{
Chris Hann \\ Max Planck Institute for Social Anthropology, Halle, Germany
}

\begin{abstract}
Drawing on four decades of field research on the Danube-Tisza interfluve, the Western zone of the Great Hungarian Plain, this paper places the "overheating" of the post-Cold War era in a longue durée perspective. The first section traces a millennium of history in terms of multi-directional migrations and civilizational encounters of various kinds: between sedentary agriculturalists and pastoral nomads, between Christian and Muslim agrarian orders, and between capitalist and socialist industrial orders. The Hungarian variant of Marxism-Leninism (unlike most other variants) relied considerably on material incentives to households. It attached high priority to transforming the countryside, which experienced an effervescent involution or "overheating" in the last decades of socialism. Since 1991, however, the market socialist synthesis has given way to a peripheral variant of Western market capitalism. Overheating is no longer a phenomenon of the rural economy, which has lost the dynamism of the socialist decades and experiences deprivation in absolute as well as relative forms. Rather, overheating is to be observed in the symbolic dimension of political legitimation, as populist political parties vie with each other in nationalist rhetoric. This overheating was evident in negative attitudes towards strangers seeking to transit this part of Hungary in the summer of 2015, a migratory process which provided a challenge to the whole of the European Union. It is argued that these attitudes in rural Hungary can be explained in terms of the ressentiments of a population which has been palpably thrown back into an underdog position on the margins of Western capitalism.
\end{abstract}

\section{ARTICLE HISTORY}

Received 23 July 2016

Accepted 28 July 2016

\section{KEYWORDS}

Civilization; populism; migrant crisis; socialism; villages

\section{Introduction}

For an ethnographer whose first studies in a particular location are focused emphatically on the present and near past, it seems a natural progression in later research to take a closer interest in the more distant past (Hann 1980, 2015a). Even if the present is always full of dramatic transformations and the ethnographer continues to visit regularly to document them, as I have done since the 1970s for the Hungarian village of Tázlár, the buzz of the contemporary fades as the years go by, while the puzzles and seductions of the more 
remote past become more salient, both in making sense of the ongoing changes and in their own right. In my case, this tendency has been encouraged by changes in temporal consciousness among villagers themselves. Very much oriented to the future in their household accumulation strategies in the last decades of socialism, most rural residents have few such options available to them nowadays. I argue that this renders them susceptible to neo-nationalism, which builds on earlier forms of populism dating back to presocialist generations.

In this paper I place the rural-urban divide, the narrowing of which was a major accomplishment of the socialist decades, in a much longer temporal framework. Drawing on civilizational analysis (Arnason 2003; Schlanger 2006), I link localized history to larger patterns of migration and political economy. On this occasion, I take not the community of Tázlár but the wider region of the Danube-Tisza interfluve as my spatial unit. Although close to Budapest, from the point of view of power holders in Istanbul and the West alike, for centuries, this space was an underdeveloped "frontier zone". This frontier was gradually conquered by peasant colonists of diverse origins who remained on the periphery of European capitalism. Their life-worlds were transformed under socialism but the years since the end of the Cold War, in particular the period since accession to the European Union in 2004, have ushered in new forms of peripherality. This configuration makes the Danube-Tisza interfluve an instructive location in which to investigate the themes of Thomas Hylland Eriksen's "Overheating" project, the focus of this Special Issue. I shall argue that in the period with which this project is concerned the heat has been transferred from the rural economy, which boomed under socialism, to identity politics and symbolic legitimation. In the final section, this argument will be illustrated with a brief analysis of the Hungarian stance in the European "migrant crisis" of 2015, in which this region played a prominent role.

\section{Civilizational Encounters and Migrations Through the Centuries}

The Carpathian Basin is an ill-defined geographical construction that has little recognition outside Hungary. For the Hungarians (Magyarok, in their own language), it has signified a homeland ever since their arrival as immigrants from the East at the end of the ninth century. Nowadays, this era is elaborately commemorated at a history theme park located (somewhat arbitrarily - see Hann 2015b) between the rivers Danube and Tisza at the village of Ópusztaszer. The state consolidated under King Stephen and his successors included large sections of the Carpathians which nowadays belong to Slovakia, Ukraine and Romania. Magyar settlement also extended west of the Danube, in territories that had once formed the Roman frontier province of Pannonia. East of the Danube the land is overwhelmingly flat. The zone between the Danube and the Tisza, the second major river of the country, is characterized by sandy soils, with dunes that impede cultivation and make agriculture altogether impossible in some districts. Some areas of the interfluve, however, are as fertile as the rest of the Great Plain to the east of the Tisza. Villages were established in these fertile spots even before the arrival of the first Hungarians. The latter followed their predecessors in combining animal husbandry with the cultivation of crops. Following Stephen's conversion, they became Christian. Their villages were vulnerable to non-Christian invaders from the East, notably the Mongols, who swept away most settlements in 1241, and then later the Ottoman Turks, whose victory at Mohács in 1526 had similar consequences for the established rural population. 
The early civilizational encounters (Arnason 2003) can be theorized in the familiar terms of a clash between marauding nomadic pastoralists and sedentary cultivators. The Ottomans, however, constituted a powerful agrarian empire. Although the network of villages was destroyed after the Battle of Mohács, market towns such as Kecskemét and Szeged flourished during the Turkish occupation of the Danube-Tisza interfluve. The local population cultivated fields in the vicinity of the towns and rented the lands of remote settlements such as Tázlár as pasture, which they visited in the summer months only.

After a century and a half the Ottoman Turks were repelled and the Habsburgs, the victorious Western power, initiated a systematic resettlement of the Great Plain. Immigrants were recruited primarily from territories that nowadays form parts of southern Germany and Slovakia. The resettlement was top-down and the Empress Maria-Theresia herself played a key role. But the re-establishment of Christian feudalism in the eighteenth century did not entail the reconstruction of the medieval settlement network. Locations like Tázlár remained puszta, that is, uninhabited, serving only as summer pasture. Such regions had a reputation for banditry, beyond the civilized pale of the urban settlements.

Towards the end of the nineteenth century, following the abolition of serfdom, the conquest of Hungary's "internal frontier" (Den Hollander 1960-1961) entered a new phase. With the break-up of noble estates, land gradually became a commodity like any other. Capitalist social relations spread unevenly. Although promoted in 1867 to the role of junior partner in the administration of the Habsburg Empire, Hungarian elites devoted more energy to the assimilation of the minorities they governed than to processes of urbanization and industrialization. In the absence of such opportunities, the expanding rural population was faced with difficult choices. In the last decades of the Habsburg Empire, hundreds of thousands migrated to North America. But in the same period, many undertook the shorter journey to the internal frontier of the interfluve, where farmland was parcelled out by banks. The pioneers of the 1870 s were able to build their farmhouses (tanyák) in fertile locations. Some succeeded in establishing large and relatively productive enterprises. Many others found themselves struggling on infertile soils to produce enough grain even for the subsistence needs of the household. Latecomers stemmed primarily from the lower strata of society in Szeged and other regions to the east. Many had little experience of family farming, and acquiring a few acres of sand dunes did little to change their status as rural proletarians. They survived by working as day-labourers for wealthier neighbours, and by sending their children to work as farm servants. These trends continued through the inter-war period of the twentieth century. Poverty levels peaked in the early 1930s when hundreds of residents received food aid in return for working for the community. At this point two small hamlets housed a few public buildings (administration, schools, churches and mills) but the great majority of inhabitants lived on more or less isolated farmsteads. The "tanya world" was a byword for backwardness. It featured prominently in populist political campaigning for radical reform of rural social and political relations. The inhabitants of these scattered farms approximated sociologist Teodor Shanin's general type of a "peasant" society, which highlights the "family farm as the basic, multi-dimensional unit of social organization", "land husbandry as the main means of livelihood" and "the 'underdog' position - the domination of peasantry by outsiders". ${ }^{1}$ 
The history of the pre-socialist era can be theorized in terms of economic backwardness and the "development of underdevelopment". While other parts of Hungary experienced the impact of capitalism differently (for example, in many parts of Transdanubia large estates persisted down to the 1940s), the resettlement of the interfluve exemplified atomizing trends as a response to demographic and economic pressures. But instead of leading to "healthy" processes of accumulation and innovation, the "civilization" of capitalism was associated with increased stratification and economic stagnation. Only in their vineyards did some immigrants introduce new technologies (the sandy soils were well suited to the production of basic table wine, for which demand was strong after phylloxera destroyed most of the country's historic vineyards in the 1890s). The need for casual labour in this sector was crucial to the survival of many poor families. But a high price was paid because alcohol abuse (in addition to wine production, the climate and soils of the interfluve were conducive to fruit trees, the harvest of which was partly used to distil brandy) wreaked havoc in this society, especially among the poor.

In the absence of economic prosperity, the main solace of the rural population in the inter-war decades (apart from alcohol) was found in nationalism. The demise of the Austro-Hungarian Empire was followed by the Treaty of Trianon (1920), which reduced the size of the country by two-thirds and left many ethnic Magyars outside its new borders. This "historic injustice" was rejected by all shades of political opinion. Following the swift suppression of the "Republic of Councils" in 1919, power was monopolized by right-wing groupings, culminating in the Nazi Arrow Cross party which capitulated to the Red Army in 1945.

There followed an experiment lasting less than half a century with an alternative variant of an industrial social order, a "socialist civilization" which did more to develop and transform Hungarian rural society in just a few decades than capitalism had been able to accomplish in the preceding century. On the interfluve as across the country the 1950s opened with an onslaught on the property rights and market relations of the old capitalist order. Coercive socialist interventions had disastrous economic consequences. They intensified the suspicion of the great majority of rural residents (not just the rich peasants classified as the "class enemy") towards left-wing power holders. Other measures of the late 1950s and 1960s, however, laid solid foundations for rural community development, in particular, of material infrastructure. In the microcosm of Tázlár, the lower hamlet was designated as the nuclear centre and tanya residents were encouraged to build new homes here. Incentives included the availability of electricity and piped water, new public buildings (both secular and religious), and cooperative shops and taverns. Many inhabitants left agriculture for jobs in new industrial factories such as the steelworks of Csepel, south of Budapest. But because resources did not allow urbanization to keep pace with industrialization, many industrial workers continued to reside in the countryside, where they were able to produce a significant proportion of their food supply and maintain continuities with previous patterns of household farming.

The last decades of socialism witnessed a remarkable transformation of material and social relations across the Danube-Tisza interfluve. Developments in this region exemplified the successful synthesis of household and large-scale (collective) production in the agricultural sector nationwide. In turn, the relative success of Hungarian agriculture can be taken as emblematic of Hungarian "market socialism" in general (Swain 1985). The key institutional innovation in this region was the "specialist cooperative" 
(szakszövetkezet), a much looser form of collective farm than the Soviet kolkhoz or its Hungarian equivalent. Joining such a cooperative signified a weakening of property rights and some obligation to share resources, including one's labour power. But property rights were vulnerable anyway, as the first repressive years of socialism had made clear. The imposition of mass collectivization in the years around 1960 was eased on the interfluve by the provision that members of the new specialist cooperatives could, in practice, carry on farming their existing plots, with only a very modest obligation to work for the collective sector. The theory was that, in the long run, this form of cooperative should develop into something like the kolkhoz, with highly qualified farm leaders organizing an increasingly industrialized productive system. But the distinctive ecology of the interfluve made it necessary to postpone this ideal socialist solution to a remote future, since to establish large mechanized farms would have meant eliminating the patchwork of vineyards and orchards which was the enduring legacy of the tanya settlement pattern. As a result, the specialist cooperatives of the 1960s remained small, with limited machinery at their disposal, under the leadership of local peasants.

Things had moved on by the time of my fieldwork in 1976-1977. With decentralization and increased use of market signals following introduction of the New Economic Mechanism in 1968, Hungarian agricultural production boomed. It did so thanks to a happy combination of increasingly efficient production on large farms organized according to socialist principles (both collectives and state farms) and exploitation of the established strengths of household farming, particularly in labour-intensive branches. The DanubeTisza interfluve was a stronghold of the latter. In the grape/wine sector, the state planted large new vineyards and built wineries for processing. At the same time, it helped individuals to maximize output in their private vineyards and to find a market for their product after the harvest.

The symbiosis of socialist and peasant agriculture was even more potent in the hograising sector, which was less ecologically specific to the interfluve. Peasants accustomed to raising two or three animals per year, one of which they would slaughter in winter and process for their own consumption, were now able to obtain cheap feed through their cooperative (either grown locally using new mechanized methods or imported from other, more productive regions of the country). The cooperative also helped with veterinary services and guaranteed purchase of the animals when they reached a specified weight. The peasant household was responsible for all the dirty work in the sties, which was often carried out by the elderly, or by the wives of men who commuted to factory jobs. I was struck by how hard people worked, but the incentives were obvious. Consumer markets expanded greatly in the last decades of socialism, allowing villagers to build lavish new houses or, more modestly, to add bathrooms and "white goods" to existing accommodation, and to buy cars.

Social inequalities increased and I detected a renewal of phenomena critiqued by populists in the past, notably the prevalence of exploitative day-labouring in the vineyard sector. But this was a price which socialist power holders were now willing to pay. By the early 1980s, the ideologically determined goal of transforming the specialist cooperative into a more conventional form of collective farm had been abandoned. Instead, with an expansion of material incentives throughout the economy, more conventional socialist institutions such as the kolkhoz were increasingly modified to resemble the specialist cooperative (Hann 1993). The Danube-Tisza interfluve exemplified these developments, 
which was made possible by the political conjuncture (a distinctive regional ecology alone would not have been enough). In the 1960s, these flexible institutions were fostered at the highest level in Budapest by Ferenc Erdei, a left-wing populist who had analysed the atrocious social conditions of his home region in the 1930s and whose dedication to socialist ideology was matched only by his determination to improve the lot of the peasantry from which he came. In the county town of Kecskemét, the market socialist path in the rural sector was astutely promoted in the 1970s by Pál Romány, the First Secretary of the Party. As with the institutionalization of the specialist cooperative across the interfluve, the appointment of an agrarian expert to lead this large county reflected a pragmatic determination of the Hungarian Socialist Workers' Party to put the maximization of output and incomes ahead of economic and political dogmas.

Two further points need to be made. First, although most peasant households profited from these measures, which allowed many to reach a higher standard of living than that of urban workers, this prosperity did not entail any moral approval of socialist principles. They attributed their successes to their own hard work, while continuing to resent socialist property policies and bureaucratic inefficiencies. Second, the intensification of existing peasant farms did not, in the majority of cases, lead to productive investment. A few took advantage of opportunities to purchase tractors and other equipment when this was authorized in the 1980s, but most of the income earned through household production was spent on consumption.

The acceleration of consumer spending had far-reaching social consequences. Hungarian meat consumption rose to be the highest in Europe, but so did suicide levels and alcohol abuse. Large sums were given away at increasingly lavish wedding parties to endow the new couple (Hann 2014). The pressures of status emulation became significant. Virtually no one had time for holidays, since animals had to be looked after and there was always some urgent task to be done around the house/farm. In short, the changes of the late socialist period were experienced by many villagers as a phenomenon analogous to Eriksen's "overheating". The pattern might be compared to involution in Java, as analysed by Geertz (1963). Agricultural production was intensified but the peasant farmers who made a critical contribution did not alter their basic production techniques. The difference to Indonesia is that, in this socialist modernization drive, a strong state promoted not "shared poverty" but an increasingly differentiated countryside. The countryside was no longer the backward peasant (paraszt) "other" of urban civilization, but a world in which those now classified as "small producers" (kistermelök) could match or exceed the income levels of the town thanks to their intimate symbiosis with socialist farms that produced on a much larger scale using industrial methods.

\section{Collapse and Migration Westwards}

According to some analysts, Hungarian market socialism was a contradiction from the beginning. Critics argued that the limited successes achieved after 1968 had already proven unsustainable long before 1990 (see Swain 1993). This makes intuitive sense in the case of agriculture: why would new generations of rural residents be willing to endure punishing routines of hard and dirty labour? Surely the kistermelök would want in due course to emulate urban workers and enjoy more leisure time? I noticed such aspirations in Tázlár in the 1980s, especially among young people of both genders and 
older women. But this would only have been feasible if the old household sector were to be replaced by capitalized private farms. In the end, the symbiosis of the socialist years was broken up not by its alleged internal contradictions but by the "system change" (rendszerváltás) of the early 1990s. This brought the privatization of virtually all socialist farms and the land itself, and confronted the new owners with radically altered market conditions. With the loss of secure outlets in the USSR and Eastern Germany, the producers of wine now had great difficulty in adapting to increasingly global competition.

Although the Danube-Tisza interfluve has lost the agrarian dynamism of the later socialist decades, it is still by no means as severely handicapped as many regions of northern and eastern Hungary. The county town of Kecskemét has enjoyed significant growth, thanks above all to the proximity of the country's principal north-south highway. The prestige investment is a Mercedes car factory, which exemplifies the capitalist rationale to invest where skilled labour is cheaply available. This factory now employs more workers than the old canning factories which reflect the food-based industries of the socialist past. Some Mercedes employees commute from villages as far away as Tázlár (a journey which takes the best part of an hour). But such investments are insufficient to compensate for the jobs lost in agriculture (Swain 2011). Levels of rural deprivation rose dramatically after 2010 under a government whose principal electoral base lies in the villages and small towns (Keller et al. forthcoming). The explanation for this paradox is the resilience of the ideology of agrarian populism (Hann and Kürti 2015).

Government workfare schemes to alleviate unemployment have been intensified since 2010. Even so, hundreds of thousands of rural Hungarians have felt that they have little alternative but to emigrate westwards in search of a job. This began in the 1990s and became legal following accession to the European Union in 2004. Cheap flights have made travel back and fore much easier over the years, but the dispersion of family members has led to a withering of kin ties and of the forms of intense sociality characteristic of villages in the late socialist period (cf. Creed 2011). Weddings and childbearing are postponed, celebrations have become modest restaurant affairs. Pigs are no longer slaughtered because it makes no economic sense to raise them in the old way when pork is more cheaply available in a nearby German-owned supermarket (Vidacs 2015). In the socialist era, house-building in villages such as Tázlár was a major occasion for mutual aid. Nowadays, few new houses are constructed and many are up for sale for extremely low prices. Housing prices are perhaps the most obvious statistical indicator of the gulf that has widened between countryside and town in the postsocialist years. Budapest is a special case, but even county capitals such as Kecskemét and Szeged are out of reach financially for most village residents. The smaller market towns of the interfluve have also experienced economic decline, but even here, property prices are still far above village levels.

One of the couples I know best in Tázlár was proud to buck the trend in the 1970s. While others were spending the proceeds of their household farming on house-building, Zsolt and Kati were the first to take a holiday abroad (a package tour to Italy). They were content to bring up their two children in social housing in the village centre, to which Zsolt was entitled when he served as Secretary of the Communist Youth League. Eventually, his job was phased out and he was obliged to take up alternative employment in the specialist cooperative, and to build a family home on a plot belonging to Kati's family on the outskirts of the village. Their eldest son studied forestry and found a job 
in another village of the interfluve, less than an hour's drive away. Their daughter qualified as a kindergarten teacher and had no trouble in finding an appropriate position in the village, where she has married. Zsolt and Kati are happy to be able to see their grandchildren regularly and to look after them for extended periods in the school holidays. They had a third child shortly before the end of the socialist era, a bright boy with good computing skills who graduated from a technical college after leaving the village school. But unlike his elder siblings, Balázs was unable to find a job in Hungary. Instead he followed friends to London, where he has worked for many years at Heathrow Airport's Hilton Hotel. His long-time girlfriend also works there; but they have not married and it is hard for them to think about planning a family together. This troubles his parents, but it is the price this family pays for the new freedoms.

Changes in domestic institutions and inter-household relations have been accompanied by radical changes in the political landscape. As noted above, policies conducing to a high measure of continuity with the peasant farming of yore were never sufficient to reconcile villagers with socialist power holders. The exceptional continuities of smallholding on the interfluve made it a stronghold of the Independent Smallholders' Party, the strongest political party of the pre-war era, which was re-established in 1989. The Smallholders campaigned strongly for the restoration of pre-socialist property relations, regardless of whether the fragmentation of modern enterprises and fields made any economic sense. After a decade of colourful controversy, following the elections of 1998, this party was out-manoeuvred by Viktor Orbán's Alliance of Young Democrats (Fidesz) and disappeared from the political landscape. Fidesz has a virtual monopoly nowadays on the interfluve, triumphing in all three elections of 2014 (at European, national and local levels). Only in a few enclaves (the most notable being the city of Szeged) have charismatic individuals succeeded in defeating the Fidesz candidate. The dominance of the governing party resembles that of the Hungarian Socialist Workers' party in the era when other parties were formally proscribed.

The new "agrarian populism" bears some affinity to the local political climate of the inter-war period. Those decades were characterized by a sharp cleavage (also prominent in literature and the arts in general) between the populists and their "other", primarily cosmopolitan (non-Magyar) elites in Budapest. The antipathy for everything which smacked of the urbánus was a product of the unbalanced development of the pre-socialist era, described above. Four decades of implementing a very different model of industrialization changed a great deal in Hungarian society. But when the key material props of the socialist system were suddenly withdrawn in the early 1990s, the old cultural ideologies demonstrated their resilience. It is instructive to look more closely at this long-term continuity in assessing state-society relations in Hungary a quarter of a century after the rendszerváltás.

Although I did not know them personally, I read some of the literature produced by Hungarian dissident intellectuals in the 1970s and 1980s. I had some sympathy with their critique of the Hungarian Socialist Workers' Party, much of it written from a leftist perspective. But my fear around 1990 was that the political party to which most of these dissidents gravitated, the Alliance of Free Democrats, would yield to that variant of liberalism which stressed "civil society" and the necessity of opening up even more fully to the market and strengthening private property. To my way of thinking, such an emulation of Thatcher and Reagan was likely to increase inequalities enormously and undo the 
very significant achievements of the later socialist period, not least in the rural sector. I was therefore more sympathetic to the other oppositionist grouping of the transition years, which emphasized not Western-style free markets but rather the softer variants of Magyar populist nationalism. The Hungarian Democratic Forum won the first free elections in 1990 and dominated the government until 1994, when the ex-communists (now known as the Hungarian Socialist Party) returned to power. In-fighting and incompetence weakened the Forum in much the same way that the Independent Smallholders' Party selfdestructed, eventually allowing Viktor Orbán to supplant them by shifting the focus of his own party, previously positioned at the liberal (even libertarian) end of the spectrum, towards increasingly nationalist, conservative agendas.

The resort to cultural nationalism in times of economic decline and multi-dimensional "dispossession" (Creed 2011; Kalb and Halmai 2011) is by no means limited to Hungary. It is found in both town and countryside (the examples explored in Kalb and Halmai 2011 are primarily urban workers). But I argue that it acquires particular force in predominantly rural regions such as the interfluve, where the roots of agrarian populism were nourished in subterranean fashion during the socialist period and where the decline from socialist prosperity to capitalist marginality has been particularly sharp (Hann 2015a). The new populist messages are disseminated in many media, from Duna television to revisionist school textbooks. Many Western critics have condemned Orbán's efforts since 2010 to muzzle judges and journalists. It is impossible to overlook the increased salience of national rituals and symbolism. The interfluve contains two of the major heritage sites cultivated to reinforce national identity through school visiting parties and tourism. One is the National Historical Memorial Park at Ópusztaszer, noted above, where demonstrations of horsemanship complement nostalgic reconstructions of pre-industrial peasant communities and the patriotism that was interrupted by socialism. ${ }^{2}$ The other is the puszta of Bugac, south of Kecskemét, another major site for enacting Hungary's shamanic traditions and the ethnic traits which render the Magyars so different from all their neighbours (Kürti 2015).

It follows from this summary analysis that contemporary Hungary is far from the model of Hayekian market economy that was my worry 25 years ago (Hann 1990). Fidesz governments since 2010 have not hesitated to intervene in the economy whenever it suits their political purposes. Land and enterprises have been re-nationalized for political reasons. The massive expansion of Workfare schemes (launched rather cautiously by the preceding socialist government) distorts labour markets in ways that Hayek would certainly not have endorsed. Some anthropologists have theorized such schemes as the disciplinary or punitive side of neoliberalism (Wacquant 2012). Such analyses may have much to commend them in urban settings, but in the countryside, there is a lot of support for these initiatives. In Tázlár, the opportunity to work for the locality in this way is greatly preferred to dependence on day-labour, even if Workfare income comes out significantly lower when calculated on a daily basis. The problems start when there are not enough slots available for all those who would like to take advantage, and the Mayor's discretionary power comes into play. It is the same at higher levels, with government concessions or bank credits dependent on who one knows in Fidesz and allied groupings. The cronyism extends to Orbán's own family and entourage. A new generation of dissidents (including a few survivors of the socialist oppositional movement) have compared the present postsocialist state to that of President Putin's Russia and theorized it in terms of "mafia" (Magyar 2016). 
Some of the features commonly bundled under the term neoliberalism can, of course, be found in Hungary today. There are elective affinities between national conservatism, an interventionist state, and the cultivation of neoliberal values such as personal responsibility and more individualist forms of "self-making" (see Harmes 2012). In Hungary, as elsewhere in postsocialist Eastern Europe, banks have greatly increased their profile in the course of expanding "everyday financialization". Yet when tens of thousands of Hungarians found themselves with negative equity following the surge of the Swiss Franc in which they had taken out their mortgages, the government intervened to negotiate compromise solutions. This particular reaction followed agitated campaigns by irate citizens. It is tempting to label them "overheated" but overall this metaphor seems less appropriate in the economic dimension today than it was in the 1970s and 1980s, when there was no unemployment, and when many people worked long hours outside their jobs because they had market-like incentives to do so, while still managing to socialize more intensively with wider circles of friends than is common in the more stratified society of today. The inhabitants of the Danube-Tisza interfluve, peasant underdogs in the pre-socialist era, were exceptional under socialism in the sense that many of them managed to avoid full incorporation into the new labour hierarchies. They prospered privately as a result of an "overheating" built on self-exploitation. Today, however, they are again underdogs in the wider configurations of global capitalism, and they have a consciousness of having lost ground in the national context. In this context, it is hardly surprising that many have become overheated in a different dimension, that of identity. As in the past, when things are not going well in the domains of politics and economics, the tendency to turn to the dimension of identity and to blame perceived enemies within (Jews and Roma) as well as without (nowadays primarily Brussels) is hard to resist.

\section{Closing Down: Reactions to the Migrant Crisis of 2015}

In the summer of 2015, Hungarians found a new "other" to blame for their relative deprivation in the form of large streams of migrants making their way through the country on their way to Germany or Sweden. Viktor Orbán was in the news for weeks on end, competing with the German Chancellor Angela Merkel for the mantle of "defender of Christian European values". 3 By coincidence, my regular late summer visit to Tázlár coincided with dramatic scenes at the Hungarian-Serbian border (particularly at the crossing of Röszke, near Szeged) and at the Keleti station in Budapest (Hann 2015c). The topic dominated the media throughout Europe and I found it instructive to compare foreign coverage with what I could read and hear inside Hungary. In the village (population nowadays around 1750) and in the nearby town of Kiskunhalas (population around 30,000), the great majority was highly critical of the stream of migránsok (this was the term generally used, rather than menekültek, refugees). The proximity of the frontier somehow brought the matter close to home. No migrants were visible in the village or the town, but everyone knew that several hundred were temporarily accommodated in a disused barracks just outside Kiskunhalas. It was asserted that taxis carrying the foreigners northwards to Budapest regularly used the minor roads of the Danube-Tisza interfluve in order to avoid police controls on the major highways, passing through villages such as Tázlár at the dead of night. The taxi drivers were thereby committing a criminal offence, but for many villagers, the migrants themselves were also tantamount to criminals, since they had entered the 
country illegally. They were certainly not wanted in Hungary. Viktor Orbán's construction of a fence to keep them out met with general approval. The general view was that a country that was exporting so much labour to more prosperous members of the European Union had no obligation to provide any help at all for new immigrants from the East.

In private conversations, a few villagers took a more generous line towards the refugees, suggesting that they deserved help rather than the scornful rejection which appeared to be driving the government's response. I think that, in some cases, this more tolerant opinion might well have been articulated because they knew I live in Germany and suspected that I would sympathize with Western criticisms of Viktor Orbán's nationalist rhetoric and fence construction. Negative Western reporting is a constant cause for complaint in much of the Hungarian media. I had no opportunity to conduct systematic surveys but I had the impression that unorthodox opinions on the migránsok were more likely to be voiced by persons who belonged to a minority of some sort, for example, the Lutheran religious minority, or the dwindling minority of villagers who had formerly sympathized with the Hungarian Socialist Workers' Party.

Of course, all human beings belong to minorities of one sort or another. Most of the contemporary population of Tázlár can trace their descent to the migrants who built their scattered farmsteads (tanyák) a century ago. Many had sváb (German) or tóth (Slovak) family names and these languages were still spoken here in the first half of the twentieth century. Only in a final massive wave of Magyarization during the Second World War did almost all of these families adopt Hungarian-sounding surnames (this was not enough to save many individuals from deportation and death in Siberia following the victory of the Red Army). In the socialist decades, when the nuclear centre grew dramatically and hundreds of isolated tanyák were abandoned, Tázlár became a modern Hungarian village. After the change of regime, there was a modest revival of interest in ethnic minorities in neighbouring settlements, which cultivated links with Slovakia and both Eastern and Western Germany, but Tázlár is nowadays an exclusively Hungarian settlement. Children do, of course, learn when they are still very young that the Magyars are themselves migrants who arrived gloriously in their present homeland in the Carpathian Basin little more than 1000 years ago. But they are not brought up to pay any heed to later migration histories or to the non-Magyar origins of a high proportion of local inhabitants. Even the few Roma households of the village communicate only in Hungarian. Neighbouring Kiskunhalas has a much larger Roma population, which the Hungarian majority of the town was prone to invoke when discussing the migránsok: "if there is still so much to be done in terms of integrating these fellow-citizens, how can we be expected to accept Muslim foreigners?" Viktor Orbán has himself made this point in arguing against EU proposals to impose a mandatory quota on all member states. His approval ratings in the opinion polls increased significantly as a result of his handling of the crisis in 2015. Orbán may be a pariah in the liberal West, but his aggressive posturing on behalf of the civilization of Christian Europe goes down well at home, especially in the countryside.

\section{Conclusion}

Hungary is an instructive setting in which to examine the post-Cold War world from the "overheating perspective". I have argued that the more familiar patterns of "acceleration" 
and "overheating" identified by Eriksen (this Special Issue) have only limited relevance here. The international mobility of labour and capital has increased since 1991, but the asymmetries of migration and direct foreign investment reflect the country's new peripheral status within a civilization with its centre to the West. In some respects, the present marginality is a return to that of the pre-socialist era rather than a "shift to a higher gear". The main cause of contemporary rural overheating in the dimension of "identity" is the collapse of the socialist civilization which enabled poor peasants to transform their collective infrastructure and narrow the gap separating them from urban elites. Peasants such as those who settled the tanya world of the Danube-Tisza interfluve in the late nineteenth century came to internalize expectations of further improvement, but these were shattered in the 1990s. The dissolution of collective farms and the privatization of their assets, including the land itself, brought wealth to a few. But for the majority, it brought uncertainty and, if not absolute impoverishment, then a stagnation and vegetation that contrasted with the forward-looking trajectories of socialist days. The disillusionment is strongest in the rural sector because, relatively, this sector was the biggest winner in the Hungarian variant of socialism; so the fall from grace is greater. But inequalities have widened within the urban as well as within the rural population. They have also widened between regions (with eastern and northern districts losing out most completely and the interfluve roughly in the middle in this respect). The ensuing tensions create fertile terrain for politicians adept at playing the nationalist card. The anti-migráns rhetoric of 2015 is a continuation of the trends which have seen internal minorities stigmatized (that is Roma and Jews) and Brussels pilloried for every action or statement that is not in keeping with the actions and statements of the true guardians of European values by the Danube.

Hungary is not alone in this regard. It was the most visible scapegoat for the obscenities of summer 2015, but it is well known that public opinion in Slovakia, the Czech Republic and Poland is roughly congruent with opinion in Hungary. This is not surprising. When German Chancellor Angela Merkel decided that Syrian refugees would be welcome in Germany, but then very soon afterwards began to insist on quotas to distribute the influx throughout the European Union, one does not have to be a strident nationalist to feel that one's country is being treated in a high-handed manner. Many Western commentators have criticized Eastern Europeans who do not understand what it means to belong to a solidary community such as the European Union. If Hungarian farmers benefit from the subsidies distributed by Brussels agricultural policies (so the argument goes), then they must also be ready to share the costs of accommodating refugees. Eastern Europeans might have had multi-cultural empires in the distant past, but they morphed into selfish nation-states under socialism and are now accused of a "compassion deficit".

Criticisms of this kind are echoed within the countries of the Visegrád Group by liberal elites in the capitals who deplore the growing xenophobia of the masses. It is true that some villagers in places like Tázlár utter the most shameful things about migránsok (and repeat them in the social media). They have never encountered a migráns in their lives. I know them as decent people, caring parents and helpful neighbours, not cryptoFascists. Hannah Arendt might not be convinced, but those who rush to condemn Eastern Europeans as backward and reactionary should bear at least three points in mind. First, during and even after the decades of socialism, most East Europeans (even those in the larger cities; in fact everywhere outside the capital) had little opportunity 
to encounter foreigners. This ignorance is no excuse for outrageous posturing of the kind that is common today, but it is well established that fear and negative stereotypes are seldom broken down until there is more concrete interaction with the groups in question. The second factor is the unambiguous evidence of increased poverty in rural society. Finally, in the context of economic decline it is important to note the new westwards migration of Hungarians themselves, especially since EU accession opened up western labour markets. Millions of Eastern European families now have one or more members working abroad (most often young people, most often in Britain). Given this background, is it surprising that the sight of millions of non-EU citizens being given assisted passage to enter the region's most prosperous country gives rise to anger and resentment? It is rather hard to learn German or English in Hungary to a level at which one could enter a prestigious segment of those foreign labour markets. Most Hungarian emigrants, including wellqualified college graduates, therefore end up in hotels and catering, or in some form of care work. Perhaps some of these mobile Hungarians will, following their experiences abroad, become more sympathetic to the region's new migránsok than their parents. But for many, both those who stay and those who leave, the dearth of opportunities within Hungary itself is the proof that the EU has failed, that their country, and in particular the large rural sector, is back in the "underdog position" from which it ephemerally escaped thanks to the socialist economic synthesis.

In some circles (at least in Western academia) it has become politically incorrect to make any distinction between those fleeing oppression and those migrating in the hope of improving their lives (and the lives of family members, who they hope will join them in due course). It is obvious that the categories and sub-categories are fluid. All of the victims and losers of unequal global forces deserve the sympathy of rich Europeans. Hungarians are undeniably prosperous compared with many, perhaps most, of those on the migration trail to Western Europe in 2015. But cosmopolitan liberal elites need to understand the realities of relative deprivation in their own backyards. They need also to recognize that the complete abolition of border controls (the logical recommendation of those who despair of drawing any distinction between economic migrants and those with an immediately compelling case for humanitarian support) is good for business, because it drives down the price of labour and boosts the rate of profit. There are some unlikely coincidences in some countries, including Germany, between the demands made by human rights activists and the recommendations of employers' lobby groups. But this response to some of the most conspicuous symptoms of contemporary "overheating" is hardly compatible with social democracy and the kinds of solidary community that European states - both in the West and in the East - have created over generations to domesticate international capital.

\section{Notes}

1. Shanin (1987, 3-4). The author specifies as an additional general characteristic "specific cultural patterns linked to the way of life of a small rural community" (Shanin 1987). He has in mind the social controls exercised in a nuclear settlement. Scattered resettlement of the puszta obviously produced conditions very different from those found in traditional villages; but immigrants brought their normative and "cognitive" dispositions with them and Shanin's general type retains its basic validity for the colonists of the interfluve in the presocialist generations. 
2. Ironically, this Park was initiated in the socialist era, the brainchild of leftist populist Ferenc Erdei (see Hann 2015b).

3. Orbán regularly gives interviews to the mass media in Germany, well aware that his views concerning migrants and Christian Europe command widespread support in German society. In one particularly inflammatory contribution at the height of the crisis he spoke of civilizational competition and alleged that, unless corrective action was taken, Muslims would threaten the kulturelle Identität of Europe. See "Am Ende werden die Muslime mehr sein als wir", Die Welt, 16th September 2015 (interview with Boris Kálnoky).

\section{Disclosure statement}

No potential conflict of interest was reported by the author.

\section{Funding}

This paper represents the confluence of two research projects supported by the European Research Council [Grant No. 295843] (Overheating, directed by Thomas Hylland Eriksen) and [Grant No 340854] (Realeurasia, directed by Chris Hann).

\section{References}

Arnason, Johann P. 2003. Civilizations in Dispute: Historical Questions and Theoretical Traditions. Leiden: Brill.

Creed, Gerald W. 2011. Masquerade and Postsocialism. Ritual and Cultural Dispossession in Bulgaria. Bloomington: Indiana University Press.

Den Hollander, Arie. 1960-1961. "The Great Hungarian Plain: A European Frontier Area." Comparative Studies in Society and History 3: 74-88, 155-169.

Geertz, Clifford. 1963. Agricultural Involution: The Process of Ecological Change in Indonesia. Berkeley: University of California Press.

Hann, Chris. 1980. Tázlár. A Village in Hungary. Cambridge: Cambridge University Press.

Hann, Chris. 1990. "Second Economy and Civil Society." Journal of Communist Studies 6 (2): 21-44.

Hann, Chris. 1993. "Property Relations in the New Eastern Europe: The Case of Specialist Cooperatives in Hungary." In The Curtain Rises: Rethinking Culture, Ideology and the State in Eastern Europe, edited by Minka Desoto, and David G. Anderson, 99-119. New York: Humanities Press.

Hann, Chris. 2014. "The Economistic Fallacy and Forms of Integration During and After Socialism." Economy and Society 43 (4): 626-649. doi:10.1080/03085147.2014.898824.

Hann, Chris. 2015a. "Backwardness Revisited: Time, Space and Civilization in Rural Eastern Europe." Comparative Studies in Society and History 57 (4): 881-911. doi:10.1017/S0010417515000389

Hann, Chris. 2015b. "Why Postimperial Trumps Postsocialist: Crying Back the National Past in Hungary." In Anthropology and Nostalgia. Ethnographic Studies, edited by Olivia Angé, and David Berliner, 96-122. New York: Berghahn.

Hann, Chris. 2015c. "The New Völkerwanderungen: Hungary and Germany, Europe and Eurasia." FocaalBlog. Accessed September 11. http://www.focaalblog.com/2015/09/11/chris-hann-thenew-volkerwanderungen-hungary-and-germany-europe-and-eurasia/.

Hann, Chris, and László Kürti. 2015. "Agrarian Ideology and Local Governance: Continuities in Postsocialist Hungary." In Rytî́ z Komárova-K 70. narozeninám Petra Skalníka [Knight from Komárov-To Petr Skalník for his 70th Birthday], edited by Adam Bedřich, and Tomáš Retka, 83-106. Praha: AntropoWeb.

Harmes, Adam. 2012. "The Rise of Neoliberal Nationalism." Review of International Political Economy 19 (1): 59-86.

Kalb, Don, and Gábor Halmai, eds. 2011. Headlines of Nation Subtexts of Class: Working-Class Populism and the Return of the Repressed in Neoliberal Europe. New York: Berghahn. 
Keller, Judit, Katalin Kovács, Katalin Rácz, Nigel Swain, and Monika Váradi. Forthcoming. "Workfare Schemes as a Tool for Preventing the Further Impoverishment of the Rural Poor." Eastern European Countryside 22.

Kürti, László. 2015. "Neoshamanism, National Identity and the Holy Crown of Hungary." Journal of Religion in Europe 8: 1-26.

Magyar, Bálint. 2016. Post-Communist Mafia State. The Hungarian Case. Budapest: Central European University Press \& Noran Libro.

Schlanger, Nathan, ed. 2006. Techniques, Technology and Civilisation/Marcel Mauss. New York: Berghahn.

Shanin, Teodor. 1987. "Introduction: Peasantry as a Concept." In Peasants and Peasant Societies, edited by Teodor Shanin, 2nd ed., 1-11. Oxford: Blackwell.

Swain, Nigel. 1985. Collective Farms Which Work? Cambridge: Cambridge University Press.

Swain, Nigel. 1993. Hungary: The Rise and Fall of Feasible Socialism. London: Verso.

Swain, Nigel. 2011. "A Post-Socialist Capitalism." Europe-Asia Studies 63 (9): 1671-1695.

Vidacs, Bea. 2015. "From Pig-Sticking to Festival: Changes in Pig-Sticking Practices in the Hungarian Countryside." In Economy and Ritual: Studies of Postsocialist Transformations, 79-106. New York: Berghahn.

Wacquant, Loìc. 2012. "Three Steps to a Historical Anthropology of Actually Existing Neoliberalism." Social Anthropology 20 (1): 66-79. 